\title{
Translators' Introduction to the Second Edition
}

Introduction to Metaphysics is no textbook presentation of a traditional field of academic philosophy. Presupposing that his audience is acquainted with that tradition, Heidegger plunges into a radical interrogation of its central concepts - forcing us to ask what we mean when we say that something $i$, making us wonder how Being can mean anything to us at all, and challenging us to rethink our own existence as human beings. Exposing unsuspected roots of our language and thought, Heidegger brings a new urgency to ancient questions. The text also serves as an effective entry point to many of the distinctive questions and themes of his own philosophical project.

Heidegger had originally presented his Introduction to Metaphysics as a lecture course at the University of Freiburg in the summer semester of 1935 . In 1953, in his preface to the seventh edition of his 1927 masterwork, Being and Time, he suggested that for an elucidation of the question of Being raised by this text, "the reader may refer to my Einführung in die Metaphysik, 
which is appearing simultaneously with this reprinting." ${ }^{\prime \prime}$ It attests to the importance he attached to this work that Heidegger would choose this course, from among the dozens of manuscripts of lecture courses held over the decades of his teaching career, as the first to present for general publication, and that he would see fit to introduce this Introduction as a companion, indeed a rightful heir, to Being and Time, the book that established him as a preeminent philosopher of his age.

Introduction to Metaphysics deserves this status, for the range and depth of its thought as well as for its intricate and nuanced style. Although the volume consists of a series of classroom lectures, it is composed with great care. Nearly every paragraph contains a series of plays on words that exploit the sounds and senses of German, and often of Greek, in order to bring us closer to a genuine experience of primordial phenomena: beings, Being, and Dasein.

In order to orient readers who are new to Heidegger, it may be best to begin by commenting on these three words and our reasons for translating them as we do.

Das Seiende: beings; what is; that which is. Heidegger's expression das Seiende is broad enough to embrace anything that

I. Being and Time, trans. John Macquarrie and Edward Robinson (New York: Harper and Row, 1962), 17. The 1953 edition of Einfübrung in die Metaphysik was published by Max Niemeyer Verlag (Tübingen). Niemeyer has continued to publish the book, and it has also been published in the series of Heidegger's collected works as Gesamtausgabe, vol. 40, ed. Petra Jaeger (Frankfurt am Main: Vittorio Klostermann, 1983). The Gesamtausgabe edition includes the Niemeyer edition's pagination; our translation also includes this pagination for the reader's convenience. In citing Introduction to Metaphysics we will use the abbreviation "IM" followed by a page reference according to the Niemeyer edition, which will allow the reader to find the passage both in our translation and in the two German editions. 
is something instead of nothing, any entity with which we may have dealings of any sort. One helpful passage in this text suggests the range of things that may count as beings, including vehicles, mountains, insects, the Japanese, and Bach's fugues (IM 58). Das Seiende (or the equivalent Seiendes) often refers to beings in general and as a whole, as in the opening question of the book, "Why are there beings [Seiendes] at all instead of nothing?" It should be noted that the German expression, unlike the English "beings," is not plural, and is translated most literally as "what is" or "that which is." (Occasionally, Heidegger describes something as seiend. We have translated this verbal adjective as "in being.") The term Seiendbeit, "beingness," refers to the essential characteristics of beings as such, or that which characterizes beings as beings. According to Heidegger, the tradition of metaphysics has primarily focused on grasping this beingness through some scheme that categorizes beings and subordinates some to others: for instance, Platonism concentrates on the "forms" as the beings that most fully exemplify beingness and lend a derivative beingness to lesser beings. But there is a deeper, unasked question that the metaphysical tradition ignores: the question of what allows us to understand beingness in the first place.

Das Sein: Being. For Heidegger, Being is not any thing. It is not $a$ being at all, but concerns the meaningful disclosure of beings as beings. Many passages in Being and Time and Introduction to Metaphysics use the word "Being" to refer to the distinctive way in which some sort of thing is (for instance, the Being of a school, IM 25-26). "Being" in general can mean beingness, the essential characteristics of beings as such, which have been investigated by traditional metaphysics. However, to move beyond metaphysics, Heidegger also asks how it is that beings in their beingness are meaningfully available to $u s$ at all. What allows us to go about interpreting things, or making sense of them-from 
schools to trees to ourselves? In the 1930s, as we will explain below, he addresses this question in terms of a happening, an originary event thanks to which beings as such become accessible and understandable. This event may also be called "Being" in a deeper, nonmetaphysical sense. (In order to indicate this sense, Heidegger sometimes uses the locutions "Being as such" and "Being itself," as opposed to beingness or "the Being of beings": see his I953 comments at IM I4-I5 and I33.) In this sense, Being is essentially historical: it is the "fundamental happening" of history itself (IM I53). We should note that some prefer to translate das Sein as "being" with a lowercase "b," in order to fend off the impression that Heidegger means a Supreme Being that stands above or sustains all other beings. (In German, all nouns are capitalized, so there is no such implication.) Still, in our judgment, to render das Sein as "being" risks confusion, especially with "beings" as the translation for das Seiende, so we resort to the capitalized term "Being."

Finally, in the first draft of a portion of the lecture course, translated in this volume as Appendix II, Heidegger uses the obsolete German spelling Seyn for this word. This spelling fell out of use in the nineteenth century, and Heidegger's reasons for choosing it are complex, but one thing to say about it here is that he is attempting to alert his reader to a sense of the meaning of Being that has been lost or obscured in modernity. We have chosen to use the hyphenated "Be-ing" to render das Seyn. Some translators prefer "Beyng," which was an actual English spelling in the late Middle Ages; however, while Seyn would have been recognizable, if old-fashioned, to a German reader, "Beyng" strikes us as so outlandish as to be off-putting to the English reader. "Be-ing" invites the reader to reflect on the verbal, temporal meaning of Being without this jarring effect. 
Dasein: A word left untranslated in most renderings of Heidegger's work, "Dasein” as defined in Being and Time denotes that being for whom Being itself is at issue, for whom Being (especially its own Being) is in question. For the most part, in Heidegger, this being is us, the human being, although Dasein is not simply equivalent to humans; Heidegger insists that Dasein is not an anthropological, psychological, or biological concept. It may help to think of Dasein not as a particular sort of being, but as a condition into which human beings enter, either individually or collectively, at a historical juncture when the Being of beings becomes an issue for them, or Being as the event of meaningful disclosure takes place for them. In this text, Heidegger often uses phrases that conceive of Dasein as a conditionsuch as "historical Dasein," "our Dasein," "human Dasein," or "the Dasein of a people." In everyday German, the word Dasein is used just as we use the word "existence"; readers may always substitute "existence" for "Dasein" in order to get a sense of how Heidegger's statements would have sounded to his original audience. However, Heidegger consistently sees the Latin term existentia as misleading and superficial (see IM 49, I38), so it is preferable to interpret Dasein in terms of its root meaning. This root meaning is usually rendered in English as "Being there," but when Heidegger hyphenates Da-sein, we have employed the equally valid and perhaps more vivid translation "Being-here." Dasein means inhabiting and existing as a Here, a site within which Being and beings can meaningfully appear (IM I56).

With these basic terms in place, we can sketch the general development of Heidegger's thought.

Heidegger's "early" phase culminates in the monumental $\mathrm{Be}$ ing and Time (1927). The main thesis of this work is that Being 
can be understood only in terms of time: that is, Dasein's temporality is the context in terms of which Dasein can encounter anything as something that is, instead of nothing at all. This thesis is not fully developed in the work as it stands; Heidegger broke off the project before it was completed. The book does show that there are several distinct ways of Being: what it means for a "present-at-hand" entity to be is to be given as an object to a theoretical gaze; a "ready-to-hand" entity, such as a tool, is when it fits into a meaningful network of purposes and functions, or a "world"; and Dasein is by existing as a self-related being, for whom its own Being is at issue as it goes about inhabiting the world. In other words, each of us acts and handles things in terms of some possible ways for us to be (say, being a physician, a mother, or an Italian). Normally we do not explicitly choose our identity, but simply behave the way "one" does in our community-we conform to the norm. However, experiences such as anxiety and the call of conscience can shock an individual into choosing who he or she is, in the face of his or her own mortality. One then exists "authentically," at least for a while. An authentic individual lives in a way that is appropriate to a temporal being - that is, a being who has always already been "thrown" into some situation, who "projects" possibilities, and who dwells among other beings in a present world. Our temporality is historical: each of us is a member of a community with a shared inheritance. In section 74, Heidegger suggests that through "communicating and struggling," a people may find a way to forge a destiny from its heritage.

Again, Being and Time intended to show that Dasein's temporality makes it possible for Dasein to understand all kinds of Being. Presence at hand, which the tradition has generally identified with Being in general, would then be unmasked as only one type of Being - a narrow, objectified way of Being that is 
made available by the present, in the temporal sense. An insight into the broader dimensions of temporality would then make it possible for us to acknowledge and comprehend more ways of Being, including our own, in some unitary way.

Why did Heidegger break off Being and Time before establishing its main thesis? It seems that the book's approach was insufficiently historical, in his view, at least in its manner of presentation. Despite the fact that Heidegger describes us as profoundly historical beings, the thesis of Being and Time sounds rather ahistorical, as if a fixed and eternal essence of Dasein determined, once and for all, the range of meanings that beings can have. This way of thinking does not reflect our indebtedness to the movement of history, which can thrust new meanings upon us. In his later reflections on Introduction to Metaphysics, Heidegger accordingly speaks of a move "from the understanding of Being to the happening of Being" (see page 233 below). ${ }^{2}$

In 1933, Heidegger enthusiastically welcomed Hitler's rise to power and lent his hand to the new regime by serving for a year as the first Nazi rector of the University of Freiburg. In his inaugural speech, he condemns traditional academic freedom and calls on the university to perform "knowledge service" as a complement to labor service and military service. ${ }^{3}$ During his year as rector he delivered a lecture course that at one point apparently endorses the "annihilation" of the internal enemies of the people

2. The precise nature of the "turn," or the shift from "early Heidegger" to "middle" or "later Heidegger," is a classic topic in the secondary literature. Some deny that there is any fundamental shift at all. Most interpreters, however, would agree that beginning around 1930, Heidegger emphasizes our indebtedness to Being as a happening or event.

3. "The Self-Assertion of the German University," trans. Lisa Harries, in Martin Heidegger and National Socialism: Questions and Answers, ed. Günther Neske and Emil Kettering (New York: Paragon House, 1990). 
(Volk), and a seminar that argues that the state must be led by the absolute will of a supreme leader (Führer). ${ }^{4}$

Interpreters differ widely, and often acrimoniously, on whether Heidegger's Nazism was a passing aberration or a long-term commitment, and whether it was due to a character defect or a philosophical error. ${ }^{5}$ We would argue that his politics are connected to some enduring elements in his philosophy. Heidegger believed that a moment of communal authenticity, such as he had suggested in section 74 of Being and Time, had arrived. Drawing on his understanding of historicity, he held that a movement based on a particular people's heritage was truer and deeper than any politics based on universal, abstract principles (such as liberal democracy or communism, as he saw them). ${ }^{6}$ But

4. Being and Truth, trans. Gregory Fried and Richard Polt (Bloomington: Indiana University Press, 20I0), 73; Nature, History, State, trans. Gregory Fried and Richard Polt (London: Bloomsbury Academic, 2013), Session 7.

5. Heidegger's political involvement has generated great controversy in several cycles of discussion since the end of the war. For reliable biographies, readers may consult Hugo Ott, Heidegger: A Political Life, trans. Allen Blunden (New York: Basic Books, 1993), and Rüdiger Safranski, Martin Heidegger: Between Good and Evil, trans. Ewald Osers (Cambridge, Mass.: Harvard University Press, 1998). For further discussion, see Richard Wolin, ed., The Heidegger Controversy: A Critical Reader (Cambridge, Mass.: MIT Press, 1993); Tom Rockmore and Joseph Margolis, eds., The Heidegger Case: On Philosophy and Politics (Philadelphia: Temple University Press, 1992); Gregory Fried, Heidegger's Polemos: From Being to Politics (New Haven, Conn.: Yale University Press, 2000). More recently, considerable debate has been sparked by Emmanuel Faye's Heidegger: The Introduction of Nazism into Philosophy, trans. Michael B. Smith (New Haven, Conn.: Yale University Press, 2009); for a correspondence with Faye about his work, see Gregory Fried, "A Letter to Emmanuel Faye," Philosophy Today 55:3 (Fall 20II): $219-52$.

6. In the winter semester of $1933-34$, Heidegger identifies Platonism as the root of the powers "against which we must struggle today" for the sake of "the finitude, temporality, and historicity of human beings": Being and Truth, 129. 
this is not to say that his philosophical ideas can lead only to fascist politics, or that they are exhausted by such politics. Readers should also know that the textual evidence shows that Heidegger increasingly distanced himself from Nazism - or at least, from the actual practice and dominant mentality of the movement, as opposed to what Introduction to Metaphysics calls its "inner truth and greatness" (IM I52). By I940, Heidegger had developed a metaphysical critique of standard Nazi ideology — without drawing any closer to liberal or leftist points of view. ${ }^{7}$

In $1936-38$, Heidegger composed the first of a series of private texts that were to be published only after his death: Contributions to Philosophy. ${ }^{8}$ The shift from traditional metaphysics to a new, historical understanding of Being is presented here as an epoch-making transition from "the first inception" to "the other inception." In the other inception, Being is to be grasped as a fundamental happening: das Ereignis, the appropriating event. This event can found Dasein by tearing open a "time-space" or "site of the moment" where Dasein is "appropriated." Then we can achieve genuine selfhood and learn to "shelter" truth in particular beings, such as works of art, but only if "truth" is understood as an openness to the meaningfulness of things, not as a set of correct propositions about the world that we somehow hide away and safeguard. It was clearly such an appropriating event that Heidegger had been hoping to find in the National Socialist revolution, but this text subjects the typical Nazi worldview to some strong criticism, insisting that a Volk is never an end in itself. ${ }^{9}$ Heidegger begins to look less toward politics than

7. See Richard Polt, "Beyond Struggle and Power: Heidegger's Secret Resistance," Interpretation 35:I (Fall 2007): II-40.

8. Contributions to Philosophy (Of the Event), trans. Richard Rojcewicz and Daniela Vallega-Neu (Bloomington: Indiana University Press, 20I2).

9. Ibid., 78, I09, 252, 3I6. 
toward poetry - specifically, the poetry of Friedrich Hölderlin, which suggests new ways for the Germans to seek themselves. Heidegger's later writings move ever farther from the domains of willful action and power, emphasizing the need to wait. ${ }^{10}$

In the context of these broader developments, Introduction to Metaphysics comes into view as a transitional text where Heidegger is exploring a number of key issues. Its initial question- "Why are there beings at all instead of nothing?"-was raised by Leibniz, one of the "greatest" German thinkers (IM 92). ${ }^{11}$ But whereas Leibniz answers the question by identifying God as the first cause and develops a rationalist metaphysics, Heidegger denies us any answer, and instead uses the question to raise a still deeper one: "How does it stand with Being?" (IM 25). That is, what is the sense of beingness for us, and how is it that we have any such understanding of what it means to be? Heidegger's investigations take him back to the language, philosophy, and tragic poetry of the Greeks. He claims that in the course of Western history, and particularly under the influence of Platonism, Being has been restricted: it has been opposed to becoming, to seeming, to thinking, and to the ought. But as Heidegger points out in the final hour of his lecture course, this restricted sense of Being must be insufficient: after all, becoming, seeming, thinking, and the ought are not nothing, but have their own ways of Being (IM I55). Metaphysics can come alive again philosophically only if we trace the genealogy of the four restrictions and recapture the primal sense of "physics": the Greek experience of Being as phusis, or emerging

Io. See especially Country Path Conversations, trans. Bret W. Davis (Bloomington: Indiana University Press, 20IO).

II. For Heidegger's interpretation of Leibniz, see his 1928 lecture course The Metaphysical Foundations of Logic, trans. Michael Heim (Bloomington: Indiana University Press, 1984). 
and enduring power and presence. This original experience of presence lies at the root of the Western interpretation of Being. Yet presence itself may prove to be inadequate to grasp Being in its full breadth and depth. The entire question of Being thus needs to be rethought, and Heidegger suggests that in order to challenge Being as presence, we must rethink the question of Being and time (IM I57).

This conclusion makes it clear why Heidegger would later recommend Introduction to Metaphysics as a companion to Being and Time, and it points the way to Heidegger's later work. Without subscribing to Being and Time's specific claims or adopting all its terminology, Introduction to Metaphysics vividly drives home the need to reflect on what it means to be, and on the surprising fact that Being means anything to us at all. The more historical approach of Introduction to Metaphysics is typical of Heidegger's cast of thinking after 1930, where the question of Being is not a search for transhistorical absolutes but a way of leaping into our own historicity, as Heidegger understands it. In alluding to "a completely different domain of questioning" (IM I57, cf. I5) that would inaugurate "the other inception" (IM 29), the text anticipates the transformative ambitions of the Contributions to Philosophy.

Along the way, Introduction to Metaphysics touches on a host of difficult issues, such as the meaning of "metaphysics" itself. While metaphysics is presented here as a profound and genuine impulse, Heidegger's investigations of the history of metaphysics and its roots in phusis ultimately imply that a new beginning of thought must be other than metaphysical (cf. IM I5). Other challenging topics that are raised in the text include the ontological implications of grammar and logic, the relation between Being and Nothing (das Nichts), and the nature of truth and language. For detailed investigations of such topics, we refer 
readers to the anthology $A$ Companion to Heidegger's “Introduction to Metaphysics."12

The political dimension of the text requires some special comments. As compared to the speeches, lecture courses, and seminars from Heidegger's year as rector in $1933-34$, Introduction to Metaphysics reads less like the urgings of an enthusiast and more like an internal critique of National Socialism. Heidegger repeatedly praises recent developments in Germany while snatching the praise away in his next breath by claiming that the developments remain superficial (e.g. IM 36, 39, 4I, 8I, I29). In short, he attempts to be more revolutionary than the revolution itself. The question of whether Heidegger "is a Nazi" in this text is thus less interesting than the question of what it means to be a Nazi. Heidegger is surely raising that question, as well as the broader questions of what it means to be German, to be Western, and to be human. The lines of questioning he initiates can hardly be reduced to a particular party's program or ideology.

Nevertheless, certain themes in the text echo the most terrifying aspect of the Nazi movement: its eagerness to commit violence and murder against its perceived enemies. In particular, in his elucidation of a famous choral ode in Sophocles' Antigone, Heidegger explores the idea that human beings, or at least the great and creative ones, are uncanny and violent: they must fight against other beings and against Being itself until they are tragically crushed by Being's overwhelming power. Is this passage an apology for Nazi terror? It can be read more charitably as an investigation of the roots not merely of one political movement,

I2. Richard Polt and Gregory Fried, eds., A Companion to Heidegger's "Introduction to Metaphysics” (New Haven, Conn.: Yale University Press, 200I). 
but of perennial dimensions of human action. Readers should be aware of the variety of related concepts that Heidegger deploys in this connection (see walten in our German-English Glossary). In particular, the word Gewalt often means violence in the sense of arbitrary and willful force, but it can also mean the legitimate force employed by the institutions of the state. We have decided to translate this word uniformly as "violence," because although Heidegger "reaches beyond the usual meaning of the expression, which generally means nothing but brutality and arbitrariness" (IM II5), he seems to want to underline the radically transformative work of the Gewalt-tat and the Gewalt-tätiger, the act of violence and the doer of violence, without minimizing the danger and even the terror of such work. The root of Gewalt is walten, which we translate as "hold sway," or in its noun form as "sway"; walten might also be rendered as "prevail," "reign," "govern," or "dominate." The sway is not simply a human affair, but a characteristic of phusis itself- the powerful upsurge of the presence of beings. ${ }^{13}$ Likewise, Heraclitean polemos or "war" may lie at the root of human warfare, but it is also a deeper, ontological confrontation that affects the very process of meaning and disclosure. ${ }^{14}$

Heidegger's ontological explorations of violence and war in Introduction to Metaphysics find resonance in other texts, such as

I3. In modern German the verb walten is usually used in stock phrases such as walten lassen, meaning to allow (a certain attitude, such as prudence) to prevail, and frei schalten und walten, or freely doing as one likes. On the more radical sense of walten in Heidegger, cf. Jacques Derrida, The Beast and the Sovereign, vol. 2, trans. Geoffrey Bennington (Chicago: University of Chicago Press, 20II); see in particular 280-90 on Introduction to Metaphysics.

I4. See Heidegger, Being and Truth, 72-76; Fried, Heidegger's Polemos; Hans Sluga, "Conflict is the Father of All Things: Heidegger's Polemical Conception of Politics," in Polt and Fried, A Companion to Heidegger's "Introduction to Metaphysics." 
the contemporaneous "The Origin of the Work of Art," where he presents great artworks as embodying the never-ending strife between world (a realm of shared meaning) and earth (the uninterpreted basis of meaning). Throughout the mid-thirties, Heidegger appears to celebrate creative conflict; he seems to believe that National Socialism may find an appropriate way to spur such creativity and to revive an ancient understanding of techne as a forceful and disclosive struggle. But with his turn away from power and will, and his developing critique of modern technology, Heidegger develops a less violent understanding of what constitutes human greatness, as is evident when he returns to Antigone in a lecture course of $1942 .{ }^{15}$

The question of technology brings us back to the most controversial and oft-quoted line in Introduction to Metaphysics (IM I52): "In particular, what is peddled about nowadays as the philosophy of National Socialism, but which has not the least to do with the inner truth and greatness of this movement (namely, the encounter between global technology and modern humanity), is fishing in these troubled waters of 'values' and 'totalities."' Particularly problematic has been the status of the phrase within parentheses, which appeared that way in the 1953 edition so as to indicate, by Heidegger's own convention, that he had written it in 1935 (as opposed to brackets, which he used to indicate material added later on). When the book was published, the young Jürgen Habermas wrote a letter to the editors of the Frankfurter Allgemeine Zeitung, declaring his outrage that Heidegger could

I5. See Heidegger, Hölderlin's Hymn "The Ister" (Bloomington: Indiana University Press, 1996), pt. 2; Clare Pearson Geiman, "Heidegger's Antigones," in Polt and Fried, A Companion to Heidegger's "Introduction to Metaphysics." On Heidegger's turn away from the will, see Bret W. Davis, Heidegger and the Will: On the Way to Gelassenheit (Evanston, Ill.: Northwestern University Press, 2007). 
publish in 1953 , without comment or retraction, his words of 1935 hailing Nazism. ${ }^{16}$ In the ensuing controversy, Christian Lewalter argued in Die Zeit that the passage in question means that "the Nazi movement is a symptom for the tragic collision of man and technology, and as such a symptom it has its 'greatness,' because it affects the entirety of the West and threatens to pull it into destruction." Heidegger himself then wrote to Die Zeit to confirm that Lewalter's "interpretation of the sentence . . . is accurate in every respect" (for the text of Heidegger's letter, see the editor's afterword in this volume). In brief, a concerted attempt was made to characterize this passage as a condemnation of the hubristic aspirations of movements such as National Socialism that sought a monstrous "greatness" on the basis of a total control of humanity and nature through conquest and technology; the "inner truth" of the movement could then be taken as the historical importance of a phenomenon whose profound, if unsettling, significance defines the nihilism of the times. ${ }^{17}$

The trouble with this explanation is that Heidegger did not add the parenthetical remark in 1935 or soon thereafter. In his prefatory note to Introduction to Metaphysics, Heidegger claims

I6. Jürgen Habermas, letter to Frankfurter Allgemeine Zeitung, July 25, 1953, translated in Wolin, The Heidegger Controversy, 190-97. See also Wolin's introduction to the Habermas letter for an overview of the history of the passage in question. The reference to the "inner truth" of Nazism is not unique in Heidegger's work: in his 1934-35 course on Hölderlin he also uses the phrase. The printed version of that text unfortunately misreads Heidegger's abbreviation for "National Socialism" as "natural science": Hölderlins Hymnen "Germanien” und "Der Rhein," Gesamtausgabe, vol. 39, rev. ed. (Frankfurt am Main: Vittorio Klostermann, 1989), 195. See Julia Ireland, "Naming Physis and the 'Inner Truth of National Socialism': A New Archival Discovery," Research in Phenomenology 44:3 (20I4).

I7. On Lewalter's and Heidegger's contributions to the discussion, see Wolin, The Heidegger Controversy, I87-88. 
that material in parentheses was written at the time of the lectures and that material in brackets was added during later reworking of the text; in his 1966 interview with Der Spiegel, he explicitly asserted that the parenthetical remark "was written in my manuscript," but that he did not read it aloud for fear of Party informers. ${ }^{18}$ Nevertheless, subsequent scholarship has shown that many of the passages in parentheses should have been in brackets, and the insertion about "the encounter between global technology and modern humanity" is one of these. ${ }^{19}$ The reader must judge the meaning of this passage in consideration of the fact that Heidegger did not, at least in 1935 when the lectures were originally delivered, explain the significance of National Socialism in terms of the parenthetical remark.

We leave it to readers to judge the political implications of Introduction to Metaphysics, with the caution that Heidegger's

I8. "Der Spiegel Interview with Martin Heidegger," in The Heidegger Reader, ed. Günter Figal, trans. Jerome Veith (Bloomington: Indiana University Press, 2009), 324.

19. Otto Pöggeler attests that the parenthetical remark was very deliberately added in 1953 as the lectures were being prepared for publication: Martin Heidegger's Path of Thinking, trans. Daniel Magurshak and Sigmund Barber (Atlantic Highlands, N.J.: Humanities Press International, 1987), 278; see also Wolin, The Heidegger Controversy, I88. The three student assistants who worked on the page proofs of Introduction to Metaphysics upon its publication have all asserted that this insertion was not part of the original text, and furthermore that Heidegger changed the phrase "greatness of N. S." to "greatness of this movement": see Hartmut Buchner, "Fragmentarisches," in Erinnerung an Martin Heidegger, ed. Günther Neske (Pfullingen: Neske, I977), 47-5I, esp. 49. For further discussion of the textual history and its significance, see editor Petra Jaeger's afterword, in this volume; Dominique Janicaud, "The Purloined Letter," in Rockmore and Margolis, The Heidegger Case; and Theodore Kisiel, "Heidegger's Philosophical Geopolitics in the Third Reich," in Polt and Fried, A Companion to Heidegger's "Introduction to Metaphysics.” 
contemporary references and allusions need to be researched with some care. For example, when he makes approving use of Knut Hamsun for an example of talk about Nothing (IM 20), or when he criticizes Theodor Haecker's What is the Human Being? (IM I09), his original audience might well know that Hamsun, a Nobel Prize-winning writer, was a Nazi sympathizer, whereas Haecker, a Catholic theologian, advanced a clearly anti-Nazi argument.

Regardless of its political entanglements, Introduction to Metaphysics remains, first and foremost, a powerful and provocative work of philosophy. Heidegger's impassioned lectures resonate with each other and with us, leaving us with a wealth of questions. What is the difference between beings and nothing? What is the relation between Being and Nothing? How does Being come to have any meaning for us? Does our ordinary disregard for such issues blind us to our history and condemn us to a superficial relation to the world? Do our ordinary science and logic separate us from the truth? What is truth in the first place? What is language? What is thinking? What is it to be human at all?

In the English-speaking world, the importance of Introduction to Metaphysics was in part established by the fact that, in 1959, it became the first book-length work by Heidegger to be translated into English, three years before a translation of Being and Time itself appeared. ${ }^{20}$ In effect, the Introduction to Metaphysics introduced Heidegger to the English-speaking world. Ralph Manheim had undertaken the daunting task of translating

20. An Introduction to Metaphysics, trans. Ralph Manheim (New Haven, Conn.: Yale University Press, I959). 
Heidegger's highly idiosyncratic prose, and if we judge the results in consideration of the fact that he had few models to work with, Manheim's effort stands as a landmark.

Our own translation, while approximating the fluency of Manheim's work when possible, hews to a stricter standard of accuracy and uses terminology that has become generally accepted in Heidegger translations. We have also tried to maintain a high degree of consistency in conveying key concepts. The point of this procedure is to let readers form their own interpretations of Heidegger's words, based on their knowledge of all the contexts in which they appear. A common objection against so-called literal translations is that a single word can have many meanings. This is true, but the best way to suggest the shifting pattern of the meanings of a German word is to use one word in English that is amenable to undergoing a similar series of uses. For example, when we consistently use "fittingness" to translate Fug, we do not mean to imply that the word should always be understood according to some single formula, such as a dictionary definition. The various meanings of "fittingness" in this text must be gathered from its successive contexts, just as one would understand the senses of Fug if one were reading the German text. The German-English Glossary in this volume provides a starting point for readers who wish to investigate Heidegger's vocabulary further and to discover linguistic kinships among his words. Such relationships can be imitated only imperfectly in English. There are no solutions to genuine problems of translation, only temporarily satisfactory placeholders for what thoughtful readers should themselves take up as a question about language. The only thing left is to learn German.

We have made selective editorial interventions for the sake of a full understanding of this book and its context. First, consulting the more recent German editions of Heidegger's text, 
we have indicated points where parentheses in the 1953 edition have now been revised to brackets to show that the material was written after 1935. We have also provided bibliographical references for literary and philosophical works that Heidegger mentions, and we have occasionally commented on the contents of these works when we believe that such commentary would enhance the understanding of his lectures. Where Heidegger's language becomes especially difficult or where the sense depends in part on the German itself, we have provided interpolations of the German words - or, where the language is ambiguous or especially complex, footnotes giving the German for entire phrases or sentences. We have also provided the pagination from the Niemeyer edition in the margins of the lecture course, and the pagination from the Gesamtausgabe, or collected edition of Heidegger's writings, in the margins of the appendixes and the editor's afterword. This latter pagination is marked as "GA" plus the page number.

Our practice has been to transliterate individual Greek words, so that readers unfamiliar with the language may easily track the use of these terms. We have used the Greek alphabet in longer citations, on the assumption that any readers who study the details of these longer passages will know Greek and will not need a transliteration. In footnotes, we have also frequently provided conventional translations of Greek passages, since Heidegger's own interpretive translations often deliberately depart from what scholars would generally recognize as conventional renderings, and the reader should have the opportunity to judge the extent of Heidegger's departure.

In this second, revised edition of our translation we have tried to bring the text closer to the ideal by correcting some errors and omissions and making the English more fluid and idiomatic, when that could be done without losing some significant 
element of the original. The text now includes two valuable appendixes from the Gesamtausgabe edition. The first appendix consists of Heidegger's notes for his own critique of this lecture course (perhaps dating from the late I930s); the notes show that he was dissatisfied with the opening question, "Why are there beings at all instead of nothing?" and doubted that it properly led to an encounter with "the happening of Being" itself. ${ }^{21}$ The second appendix is the original draft of a passage that roughly corresponds to Chapter 3; this draft is notable for its critical comments on Schopenhauer, Nietzsche, and Carnap. We also provide the afterword to the Gesamtausgabe edition by its editor, Petra Jaeger. In addition, we have translated the useful table of contents from the Gesamtausgabe edition, whose section headings were prepared by Jaeger on the basis of some notes by Heidegger himself; this table of contents and our own outline provide two distinct, though compatible, conceptions of the overall structure of Heidegger's lectures.

2I. For further self-critiques along these lines see Heidegger, Mindfulness (1938-39), trans. Parvis Emad and Thomas Kalary (London: Continuum, 2006), $\$ 74$ and $\$$ I09. 